\title{
Relationship among Complex Sentence Production, Implicit Learning, and Working Memory based on Structural Priming Method in Children with Specific Language Impairment
}

\author{
Woojoo Han, Dongsun Yim \\ Department of Communication Disorders, Ewha Womans University, Seoul, Korea
}

Correspondence: Dongsun Yim, PhD Department of Communication Disorders, Ewha Womans University, 52 Ewhayeodae-gil, Seodamun-gu, Seoul 03760, Korea

Tel: $+82-2-3277-6720$

Fax: +82-2-3277-2122

E-mail: sunyim@ewha.ac.kr

Received: October 5, 2016

Revised: November 9, 2016

Accepted: November 15, 2016

This work is based on a partial data from the first author's master thesis.

\begin{abstract}
Objectives: This study investigated a potential intervention strategy for children with specific language impairment (SLI) using structural priming based on syntactic characteristics and the relationship among complex sentence production, working memory and implicit learning. Methods: A total of 85 children in two different groups participated in this research $-38 \mathrm{SLI}$ children and 47 normal language (NL) children in the same age range. Following the researcher's instruction, they were to complete producing complex sentences, nonword repetition and the auditory statistical learning task. Complex sentence production task was divided into three conditions based on structural priming methods: normal priming condition, repetitive priming condition in which the same vocabularies are used and repetitive priming condition in which the different vocabularies are manipulated. Results: The results were as follows: the two groups showed higher performance in the repetitive priming conditions, but showed different patterns. The SLI group showed better performance on repetitive priming condition which used the same vocaulary, whereas NL group showed higher performance on repetitive priming condition that used the different vocabulary. Correlational analysis among complex sentence production, implicit learning and working memory showed that there was a significant different tendancies across groups. Conclusion: The result of the current study suggests language presentation strategy needs to be applied differently in each group. Additionally, examining the correlation among complex sentence production depending on priming methods, implicit learning and working memory shows the differences between the groups and methods.
\end{abstract}

Keywords: Structural priming, Complex sentence production, Working memory, Implicit learning, Specific language impairment
아동의 구문 산출 능력은 출생 후 서서히 발달해 간다. 대체로 생 후 1년을 전후하여 첫 낱말을 산출하며 2-3세가 되면 주어와 서술어 구조를 갖춘 단문들을 표현하기 시작하는데(Bloom, Lahey, Hood, Lifter, \& Fiess, 1980; Gleason, 2005), 이때는 낱말을 순서대로 나열 하는 형식으로 두 낱말 이상을 결합시켜 문장을 만든다(Kim, 2014). 그리고 이전의 연구들은 빠르면 2세 초반부터 시작하여, 만 4-5세 전후에 이르면 대부분 복문을 산출할 수 있게 된다고 보고하고 있 으며 4 세 이후 우리말의 기본문형과 필수 논항의 산출이 가능해진
다고 한다(Bloom et al., 1980; Bowerman, 1979; Kwon \& Jung, 1999; Limber, 1973). 하지만 유치원 아동들과 학령기 아동들 간의 복문 산출을 비교한 연구들을 살펴보면, 두 집단 간의 복문 산출에 유의 한 차이가 관찰되는 것으로 보아 만 4-5세 이후에 학령기까지도 아 동들의 구문 산출 능력은 지속적으로 발달되는 것으로 보인다(Nippold, Mansfield, \& Billow, 2007). 복문은 크게 내포문과 접속문으 로 나뉘는데 접속문은 두 문장이 대등한 자격으로 결합한 것이고, 내포문은 한 문장이 다른 문장의 한 성분으로 참여한 것이다. 접속 
문은 대등적으로 이어진 대등 접속문, 종속적으로 이어진 종속 접 속문으로 나뉘고 내포문은 명사절을 가진 명사절 내포문, 관형사 절을 가진 관형사절 내포문, 부사절을 가진 부사절 내포문, 인용절 을 가진 인용절 내포문, 서술절을 가진 서술절 내포문으로 나뉜다 (Lee \& Chae, 2011). 선행연구에 의하면 접속문은 연령의 증가와 함 께 꾸준히 증가하고, 내포문은 아동의 연령이 증가함에 따라 출현 빈도가 증가하다가 특정 연령을 기점으로 감소하기 시작한다고 한 다. 특히, 명사절, 서술절, 인용절 내포문의 출현율은 4-5세까지 증 가하다가 감소하며, 관형절, 부사절 내포문은 이 시기가 지나도 출 현율이 꾸준히 증가한다(Kwon \& Jung, 1999).

구문능력의 발달은 아동들이 자신의 생각을 더 효율적으로 표 현할 수 있게 하는데, 이 과정에서 매우 중요한 것이 복문 산출이다. 복문을 산출한다는 것은 단순하게 문장과 문장을 결합시키는 것 이 아니기 때문에 이때 사용되는 다양한 문법형태소의 쓰임을 정 확하게 이해하고 사용할 수 있어야 하며, 의미론적으로는 두 문장 사이의 의미관계를 정확히 이해하고 있어야만 올바른 문장을 산출 할 수 있다(Lee, 2010). 또한 주어진 단어나 어절을 조합하여 구조적 으로 적절하고 의미적으로도 오류가 없는 문장을 만들기 위해서는 문장 구조, 문장 성분들이 통합되는 규칙, 문법적 형태소, 각 단어 들 간의 의미적 관계에 대한 지식, 어휘에 대한 지식이 통합적으로 요구된다(Lee, Jeong, \& Hwang, 2013).

일반 아동들에 비해 전반적인 언어 능력이 낮다고 보고된 단순 언어장애 아동들은 구문발달에서도 유의한 지체를 나타내는데, 발달이 늦게 시작될 뿐만 아니라 발달 과정에서도 일반 아동보다 오랜 시간이 소요된다(Johnston \& Kamhi, 1984; Leonard, 1998; Morehead \& Ingram, 1973). 이러한 단순언어장애 아동이 보이는 구문발달의 지체는 조사 및 연결어미와 같은 문법형태소 사용의 결함과 다양한 구문구조를 사용하고 더 복잡한 문장을 산출하는 데 있어서의 어려움에 기인한 것이다(Hwang, 2003; Kim \& Pae, 2002; Lee et al., 2013; Lee, Choi, \& Hwang, 2014).

한편, 선행연구에서는 아동들의 구문능력을 알아보기 위해 복 문 산출을 사용한 다양한 평가방식을 고안해 왔으며 그 중 하나가 바로 구문점화(structural priming/syntactic priming)이다. 구문점 화는 언어적 반복과 관련된 연구에서 파생된 개념 중 하나로, 문장 을 산출할 때 앞서 들은 것과 같은 구조의 문장을 사용하게 되는 것 을 말하며(Bock, 1986) 이때 산출되는 문장은 앞서 들은 문장의 의 미나 어휘와 상관이 없다(Bock \& Loebell, 1990; Leonard, 2011).

구문점화는 점화 제시 횟수나 점화 시 사용하는 어휘, 제시 시점 등과같은 조건을 달리하여 다양한 방식으로 실시할 수 있다(Gámez \& Shimpi, 2016; Griffin \& Weinstein-Tull, 2003; Savage, Lieven,
Theakston, \& Tomasello, 2006). 선행연구를 살펴보면, 점화를 반 복한 아동이 구문 구조를 더 오래 기억할 수 있었으며(Gámez \& Shimpi, 2016; Huttenlocher, Vasilyeva, \& Shimpi, 2004), 이와 같은 맥락으로 일정한 기간 동안 점화를 2 번 실시한 아동보다 3 번 실시 한 아동의 점화 효과가 더 컸다고 한다(Savage et al., 2006). 또한 점 화 시 사용하는 언어 자극의 측면에서 동일한 점화문장을 사용하 는 것보다 같은 구조 안에서 다른 동사를 사용한 점화가 더 큰 점화 효과를 나타냈다는 선행연구 결과가 있다(Savage et al., 2006). 단 순언어장애 아동과 일반 아동은 구문발달에서도 다른 양상을 나 타내기 때문에 복문 산출을 촉진하는 방식에 대한 반응에서도 차 이를 나타낼 것이라 예측한다. 즉, 동일한 문장을 반복하는 것과 같 은 문장 구조 안에서 다른 어휘를 사용하여 문장을 반복하는 것에 대한 효과가 두 그룹 간에 다르게 나타날 수 있을 것이다.

구문점화 방식에 대한 다양한 연구는 구문점화를 임상적인 관 점에서 진단과 중재의 방법으로 사용하려는 시도의 결과라고 볼 수 있다(Gámez \& Shimpi, 2016; Leonard, 2011; Pickering \& Ferreira, 2008). 임상에서 한 개인의 언어를 평가하는 방식은 다양하 며, 공식 검사 도구를 사용하거나 특정 언어를 평가하는 비공식 평 가를 사용하기도 하고 아동 대상의 평가에서는 평가 대상자의 집 중력과 충분한 검사 환경의 부재 등을 이유로 자연스러운 환경에 서 자발적으로 산출되는 발화를 평가하기도 한다(Kwon \& Jung, 1999). 그러나 이러한 자발적 발화 분석은 아동들이 직접 산출한 발화만을 평가 대상으로 삼기 때문에 관찰되지 않은 대상자의 언 어 구조에 대한 이해나 산출 능력을 평가하기는 어렵다는 한계점이 있다(Bloom et al., 1980; Bowerman, 1979). 따라서 선행연구에서 는 이러한 자발적 발화 분석의 한계를 극복하는 방법으로 두 개의 단문을 제시하고 연결하게 하는 구조화된 과제를 사용하여 아동 들의 복문 산출을 연구하였으며(Lee, 2007; Seo \& Lee, 1999), 본 연 구에서는 더 나아가 구문점화를 활용한 문장 연결과제를 실시하 여 아동들의 복문 산출 능력과 언어 수행의 기저가 되는 요소들의 관계를 알아보고자 하였다. 선행연구를 참고해보았을 때 구문점화 과제는 임상적인 측면에서 효과적인 진단 방법으로 사용될 수 있으 며, 구조화된 환경 속에서 언어를 직접적으로 조작하여 제시할 수 있기 때문에 대상자의 특징이나 언어적 취약점을 고려하여 효과적 인 중재를 실시하는 데에도 큰 도움이 될 수 있다(Gámez \& Shimpi, 2016; Pickering \& Ferreira, 2008).

한편, 언어 발달의 기저가 된다고 알려진 작업기억과 암묵적 학 습이 구문점화와 관련하여 어떠한 상관성을 가지고 있는가에 대한 연구도 활발히 진행되어 왔다. 암묵적 학습(implicit learning)이란 학습하고자 하는 의도나 의식적인 노력 없이 새로운 정보를 습득 
하는 것을 뜻하는 것으로(Reber, 1967) 규칙 학습과 관련하여 언어 습득의 기저가 된다고 알려져 있으며(Graf Estes, Evans, Alibali, \& Saffran, 2007; Lany \& Saffran, 2010; Saffran, Aslin, \& Newport, 1996; Ullman, 2004; Yim et al., 2016), 발달초기부터 습득된다고 한 다(Vinter \& Perruchet, 2000). 작업기억(working memory)이란 복 잡한 인지기능을 수행할 때 요구되는 정보를 일시적으로 조작하거 나 저장하는 역할을 하는 하나의 시스템으로(Baddeley, 1992) 어휘 습득, 문장의 이해, 문장의 산출, 문법적 능력의 형성과 같은 다양 한 언어 능력과 연관되어 있는 것으로 보고되어 왔다(Adams \& Gathercole, 1995; Montgomery, 1995; Weismer, 1996). 그리고 이처 럼 언어 발달 요소들이 암묵적 학습 능력, 작업기억 능력과 밀접한 관련을 가지고 있기 때문에 많은 선행연구들에서는 낮은 암묵적 학습 능력이나 작업기억 능력을 가지고 있는 아동들이 언어 능력 에 있어서도 낮은 능력을 나타낸다고 보고하고 있다(Evans, Saffran, \& Robe-Torres, 2009; Gathercole \& Baddeley, 1990; Montgomery, 1995; Tomblin, Mainela-Arnold, \& Zhang, 2007; Yang, Yim, Kim, \& Han, 2013; Yim, Yang, \& Kim, 2015). 특히 언어 능력 을 결정짓는 중요한 단계인 문장 이해와 산출은 복잡한 언어적 지 식, 언어적 처리, 다양한 정보처리 능력 간의 상호작용이며, 그 과정 에서 지각적 처리, 언어성 작업기억, 주의, 장기기억 안의 어휘에 정 확하게 접근하기 등은 필수적으로 요구된다(Kweon \& Kim, 2004). 그리고 본 연구에서 다루고 있는 작업기억과 관련하여 Just와 Carpenter (1992)의 작업기억 모델에서는 정보의 저장과 처리의 기능은 제한된 풀(pool)에서 이루어지기 때문에 이와 관련된 요구가 개인 이 가진 작업기억의 자원을 초과한다면 그 상호작용의 결과로 정 보의 저장, 처리 능력이 떨어지게 된다고 밝히고 있다.

따라서 선행연구에서는 이러한 암묵적 학습과 작업기억을 통하 여 아동들의 언어 능력을 평가하고자 지속적으로 노력해 왔으며, 암묵적 학습, 작업기억과 또 다른 언어기제 간의 연관성에 대해서 도 꾸준히 연구해왔다. 그러한 노력 중의 하나가 바로 구문점화에 따른 복문 산출 능력과의 관계인데 최근 들어 이루어진 연구들에 서는 구문점화 효과의 유지에 대한 실험을 바탕으로, 구문점화를 가지고 있는 지식의 일시적인 활성화가 아닌 암묵적 학습의 결과로 보는 의견들이 많아지고 있으며(Bock \& Griffin, 2000; Chang, Dell, Bock, \& Griffin, 2000; Chang, Dell, \& Bock, 2006; Cleland \& Pickering 2003; Ferreira \& Bock, 2006; Pickering \& Branigan, 1998; Savage et al., 2006), 아동을 대상으로 구문점화 과제를 실시한 선 행연구에서는 높은 작업기억을 가지고 있는 아동일수록 더 많은 관계사절 문장을 산출할 수 있었다고 한다(Foltz, Thiele, Kahsnitz, \& Stenneken, 2015). 하지만 이러한 연구의 흐름에도 불구하고, 단
순언어장애 아동과 일반 아동을 대상으로 구문점화 과제를 실시 하고, 그 결과와 기저 요인들의 상관관계를 밝히고자 한 연구들은 찾아보기가 힘들다. 특히 국내의 연구에서는 점화가 화자의 심리 언어학적인 부담을 줄일 수 있다는 특성을 활용하여 말더듬 아동 과 성인, 이중언어 사용자를 대상으로 한 연구만이 제한적으로 이 루어지고 있는 실정이다.

따라서 본 연구에서는 이러한 선행연구 결과를 바탕으로 구문점 화의 제시 횟수와 구문점화 시 사용하는 어휘를 다르게 함으로써 이에 따른 아동의 복문 산출 양상이 단순언어장애 아동과 일반 아 동 간에 차이가 있는지 알아보고 이를 통해 단순언어장애 아동의 중재에 적용할 수 있는 언어자극 제시 방법이 어떤 것인지를 탐색해 보았다. 그리고 언어 발달과 점화가 가진 두 능력과의 관계를 바탕 으로 구문점화 방식에 따른 복문 산출 능력과 언어 발달 기제가 어 떠한 상관관계를 가지고 있는지 알아보고, 이것이 단순언어장애 아 동 집단의 중재에서 어떠한 의미를 함축할수 있는지를 알아보았다.

구체적인 연구 문제는 다음과 같다.

1) 집단 간(일반 아동, 단순언어장애 아동) 구문점화 방식(일반 점화, 같은 어휘를 사용한 반복 점화, 다른 어휘를 사용한 반복 점 화)에 따른 복문 산출 정반응률에 차이가 있는가?

2) 각 집단(일반 아동, 단순언어장애 아동)의 구문점화에 따른 복문 산출이 암묵적 학습 능력, 작업기억 능력과 유의한 상관관계 가 있는가?

\section{연구 방법}

\section{연구 대상}

본 연구는 서울, 경기지역에 거주하는 5-7세 단순언어장애 아동 38명(5;1-7;8세, 여 11, 남 27), 그리고 이들과 생활연령을 일치시킨 일반 아동 47명(5;10-7;6세, 여 28, 남 19), 총 85명을 대상으로 하였 다. 일반 아동의 대상자 선정 기준은 다음과 같다. (1) 부모 및 교사 에 의해 지적 능력이나 언어 능력에 결함이 없다고 보고되었으며, (2) Korean-Kaufman Assessment Battery for Children (K-ABC; Moon \& Byun, 2003) 동작성 지능 검사 결과 85점 이상이다. 또 (3) 수용·표현어휘력검사(Receptive and Expressive Vocabulary Test, REVT; Kim, Hong, Kim, Jang, \& Lee, 2009) 결과 수용 및 표현어휘 력 점수가 모두 정상 발달범주(-1 SD 이상)에 해당하여, (4) 기타 행 동, 정서, 시각 및 청각 등의 감각장애, 자폐, $\mathrm{ADHD}$ 와 같은 신경학 적 증상의 관련 장애 이력이 없으며, 구강구조, 운동 등에 심각한 결함을 보이지 않는다.

단순언어장애 아동의 대상자 선정 기준은 Leonard (1998)의 기 
준을 참고하였으며 선정기준은 다음과 같다. (1) 부모와 교사에 의 해 지적 능력은 정상 범주이나 언어 능력과 관련해서는 부족함을 보이는 것으로 보고되었으며, (2) K-ABC (Moon \& Byun, 2003) 동 작성 지능검사 결과 85 점 이상이다. 또 (3) 수용-표현어휘력검사 (REVT; Kim et al., 2009) 결과 수용 또는 표현어휘력 점수가 하나 혹은 그 이상이 - $1.25 \mathrm{SD}$ 미만이고, (4) 기타 행동, 정서, 시각 및 청각 등의 감각장애, 자폐, $\mathrm{ADHD}$ 와 같은 신경학적 증상의 관련 장애 이 력이 없으며, 구강구조, 운동 등에 심각한 결함을 보이지 않는다.

본 연구에 참여한 단순언어장애 아동 집단의 평균 생활연령은 73.18 ( $\mathrm{SD}=7.50)$ 개월, 동작성 지능지수는 평균 $103.34(\mathrm{SD}=9.81)$ 점, 수용어휘력 평균은 $55.16(\mathrm{SD}=11.11)$ 점, 표현어휘력 평균은 62.92 $(\mathrm{SD}=11.00)$ 점, 구문의미이해력 평균은 $30.87(\mathrm{SD}=12.85)$ 점이었으 며, 일반 아동 집단의 평균 생활연령은 $73.89(\mathrm{SD}=6.78)$ 개월, 동작 성 지능지수는 평균 $109.34(\mathrm{SD}=10.04)$ 점, 수용어휘력 평균은 75.89 $(\mathrm{SD}=12.45)$ 점, 표현어휘력 평균은 $83.49(\mathrm{SD}=12.42)$ 점, 구문의미 이해력 평균은 $41.06(\mathrm{SD}=9.90)$ 점이었다.

집단의 통제가 잘 이루어졌는지 확인하기 위하여 일원배치분산 분석(one-way ANOVA)을 실시하였다. 그 결과 두 집단의 생활연 령에 통계적으로 유의한 차이가 없었고, 동작성 지능 $\left(F_{(1,83)}=7.649\right.$, $p<.01)$, 수용어휘력 $\left(F_{(1,83)}=64.071, p<.0001\right)$ 과 표현어휘력 $\left(F_{(1,83)}=\right.$ $63.710, p<.0001)$, 구문의미이해력 $\left(F_{(1,83)}=17.049, p<.0001\right)$ 에서만 유의한차이를 보였다.

본 연구에 참여한 아동들의 생활연령, 동작성 지능, 어휘력 점수, 구문이해력 점수의 평균 및 표준편차는 Table 1에 제시하였다.

또한 단순언어장애 아동 집단 내 점화 방식에 따른 하위 집단의 생활연령과 동작성 지능, 수용어휘력, 표현어휘력, 구문의미이해력 에 통계적으로 유의한 차이가 없었고, 일반 아동 집단 내 점화 방식 에 따른 하위 집단의 생활연령과 동작성 지능, 수용어휘력, 표현어 휘력, 구문의미이해력에 통계적으로 유의한 차이가 없었다.

Table 1. Participants' characteristics

\begin{tabular}{lccc}
\hline Characteristic & SLI (N=38) & $\mathrm{NL}(\mathrm{N}=47)$ & $F$ \\
\hline Age $(\mathrm{mo})$ & $73.18(7.50)$ & $73.89(6.78)$ & .209 \\
Nonverbal IO & $103.34(9.81)$ & $109.34(10.04)$ & $7.649^{* *}$ \\
REVT-Receptive & $55.16(11.11)$ & $75.89(12.45)$ & $64.071^{* * *}$ \\
REVT-Expressive & $62.92(11.00)$ & $83.49(12.42)$ & $63.710^{* * *}$ \\
KOSECT & $30.87(12.85)$ & $41.06(9.90)$ & $17.049^{* * *}$ \\
\hline
\end{tabular}

Values are presented as mean (SD).

$\mathrm{SLI}=$ children with specific language impairment; $\mathrm{NL}=$ children with normal language; REVT = Receptive \& Expressive Vocabulary Test (Kim, Hong, Kim, Jang, \& Lee, 2010); KOSECT = Korean Sentence Comprehension Test (Pae, Lim, Lee, \& Jang, 2004). aKorean-Kaufman Assessment Battery for Children (Moon \& Byun, 2003). ${ }^{* *} p<.01,{ }^{* * *} p<.001$.

\section{연구 도구}

본 연구에서는 아동들의 구문점화 방식에 따른 복문 산출을 알 아보기 위해 구문점화 과제를 실시하였고, 복문 산출과 암묵적 학 습 능력, 작업기억 능력의 상관관계를 알아보기 위해 청각 통계적 학습 과제와 비단어 따라말하기 과제를 실시하였다.

\section{구문점화 과제}

집단 간 구문점화 방식에 따른 복문 산출을 알아보기 위해 점화 방식을 일반 점화 조건(점화 조건1), 같은 어휘를 사용한 반복 점화 조건(점화 조건2), 다른 어휘를 사용한 반복 점화 조건(점화 조건3), 총 3 가지의 조건으로 나누어 과제를 실시하였다. 대상자들은 각 조 건에 따라 점화문장을 듣고, 따라 말한 뒤 문장 산출 과제를 수행 하였으며 과제는 Lee (2007)의 과제를 수정, 보완하여 사용하였다. 과제에는 접속문과 내포문이 같은 비율로 사용되었으며, 접속문 과제의 경우 대등, 인과, 조건, 의도의 의미 관계로 이루어진 문장들 이 다양하게 포함되었으나 내포문의 경우에는 한국어 복문의 특성 상 보문절을 가진 내포문은 두 문장을 결합하는 과제로 사용되기 어렵기 때문에 관형절 내포문만을 과제로 사용하게 되었다. 점화 조건 1 과 점화 조건 2 의 과제는 점화문장 10 개와 목표문장 10 개로 구성되어 있으며 점화 조건 3 의 과제는 점화문장 20 개와 목표문장 10 개로 구성되어 있다. 과제를 시행하기 전에 연습문항으로 과제에 대해 충분히 이해한 뒤 본 과제를 실시하였다. 대상자는 점화 조건1 에서는 연구자의 지시에 따라 복문인 점화문장을 한 번 따라 말한 뒤, 단문 두 개를 듣고 목표문장을 산출하는 과제를 수행하게 되고, 점화 조건2의 경우에는 복문인 점화문장을 두 번 따라 말한 뒤, 단 문 두 개를 듣고 목표문장을 산출하는 과제를 수행하게 된다. 그리 고 마지막으로 점화 조건 3 의 경우 점화문장 단계에서 하나의 복문 이 아닌 두 개의 복문을 따라 말한 뒤, 단문 두 개를 듣고 목표문장 을 산출하게 된다. 이때 점화 조건 3 의 점화문장 두 개는 다른 어휘 로 구성되었으나 구조는 같은 문장이며, 각 점화 조건에서 아동들 이 산출해야 하는 목표문장은 모두 같은 문장이다. 과제에 사용된 문장들이 연구대상 아동들의 복문 산출 능력을 측정하기에 적합 한지에 대한 내용타당도를 검증하기 위해 타당도 검사를 실시하였 다. 6 명의 언어병리학 석사과정 수료 및 졸업자들에게 내용타당도 에 관한 평가를 받은 결과, 검사에 사용된 자료의 내용타당도는 $99.6 \%$ 로 타당도가 검증되었다. 구문점화 과제는 Appendixes 1 과 2 에 제시하였다.

\section{암묵적 학습 과제}

암묵적 학습 능력을 평가하기 위해 본 연구에서는 청각 통계적 
학습 과제를 사용한다. 청각 통계적 학습 과제는 대상자가 일정한 규칙을 갖고 있는 연속적인 소리 자극을 듣고 그 안에서 규칙을 찾 아내는지 여부를 확인하기 위해 사용된 과제이다. 본 연구에 사용 된 암묵적 학습 능력 평가 과제는 Saffran, Newport, Aslin, Tunick 와 Barrueco (1997)의 연구를 참조하여 제작하였다. 7 개의 자음과 4 개의 모음( ᄀ, ᄃ, ᄅ, ㅂ, ㄱ, E, 프, F, , T, I)을 사용하여 CV 조합의 음절을 12 개 만든 후 이 음절을 3 개씩 묶어 가상단어 4 개를 만든다(비다쿠, 파도티, 골라부, 토피로). 2 분 50 초 동안 3 음절의 단 어 4 개가 무작위 순서로 조합되어 제시되는데 단어 경계에 대한 단 서가 될 수 있는 심이나 강세, 억양 변화 등은 포함하지 않았다. 단 어 내 전이 확률(within-word transitional probability)은 1이며, 단 어 간 전이 확률(between-word transitional probability)은 .5이다. 과제는 학습단계와 검사단계로 나뉘는데 학습단계에서 대상자는 컴퓨터에서 나오는 소리 자극에 2 분 50 초 동안 노출되며 이후 검사 단계에서 검사자는 문항마다 청각자극세트를 제시한다. 이 때 학 습단계에서 노출되었던 자극과 처음 제시되는 자극을 보기로 제시 하면 대상자는 두 개의 보기 중 익숙한 순서로 제시되는 청각자극 을 선택한다. 총 문항수는 20 개이며 각 문항의 점수는 정반응 1 점, 오반응 0 점으로 계산한다.

\section{작업기억 과제}

본 연구에서는 음운적 작업기억을 측정하기 위한 과제로 비단어 따라말하기(Oh \& Yim, 2013) 과제를 사용한다. 이 과제는 아동에 게 청각적으로 비단어를 제시하고, 아동이 제시된 단어를 즉시 따 라 말하도록 하는 검사이다. 비단어는 $2,3,4,5,6$ 음절의 길이이며 각 음절 당 4 개씩, 총 20 개의 단어로 구성되어 있다. 대상자는 헤드 폰을 통해 20 개의 단어를 듣고 비단어를 따라하게 된다. 각 문항은

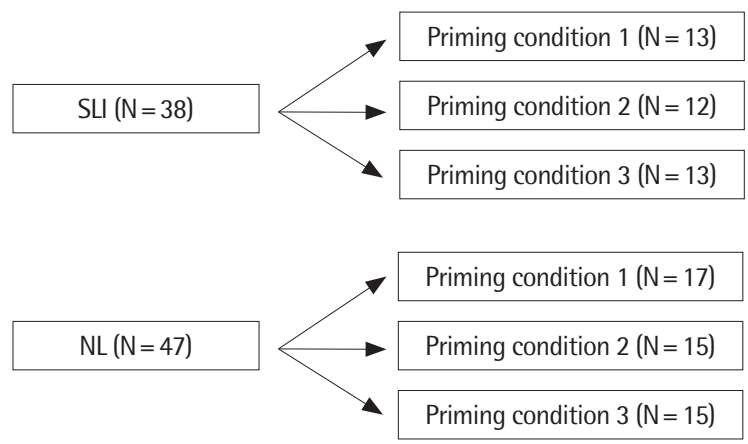

Figure 1. Sub-groups based on structural priming method. SLI=children with specific language impairment; $\mathrm{NL}=$ children with normal language; condition $1=$ normal priming condition group; condition 2 = repetitive priming condition group that uses the same vocabulary; condition $3=$ repetitive priming condition group that uses different vocabulary.
단어와 음절의 수준에서 채점되며, 본 연구에서는 단어 수준에서 채점된 결과를 사용한다.

\section{연구 절차}

구문점화 방식에 따른 복문 산출을 알아보기 위해 일반 아동 집 단과 단순언어장애 아동 집단을 구문점화 조건에 따라 각각 세 그 룹으로 나누어 실험을 실시하였다(Figure 1).

\section{통계 분석}

본 연구의 연구문제에 따라 집단 간 구문점화 방식에 따른 복문 산출에 차이를 알아보기 위하여 이원분산분석(two-way between ANOVA)을 실시하였으며 각 집단의 구문점화에 따른 복문 산출 이 암묵적 학습 능력, 작업기억 능력과 유의한 상관관계가 있는지 알아보기 위해 Pearson의 적률 상관계수를 사용하여 상관분석을 실시하였다. 모든 통계적 분석은 SPSS 18.0 for Windows 프로그램 을 사용하여 자료 분석을 실시하였다.

\section{연구 결과}

\section{집단 간(일반 아동, 단순언어장애 아동) 점화 방식에 따른 복문 산출 과제에서의 수행도 차이}

일반 아동 집단의 점화 방식에 따른 복문 산출 과제에서의 수행도 차이 일반 아동 집단 내 하위 집단의 점화 방식에 따른 복문 산출 과제 에 대한 기술통계는 Table 2 와 같다. 구문점화를 한 번 제시한 조건 에서 일반 아동은 10 점 만점에 1.82 점 $(\mathrm{SD}=0.88)$ 을 획득하여 약 $18.2 \%$ 의 정확도를 보였고, 같은 문장의 구문점화를 두 번 제시한 조건에서 일반 아동은 10 점 만점에 3.73점 $(\mathrm{SD}=1.33)$ 을 획득하여 약 $37.3 \%$ 의 정확도를 보였다. 그리고 구문 구조는 같으나 어휘가 다 른 문장의 구문점화를 두 번 제시한 조건에서는 10 점 만점에 4.67 점 $(\mathrm{SD}=2.71)$ 을 획득하여 약 $46.7 \%$ 의 정확도를 보였다.

Table 2. Complex sentence production based on structural priming condition in sub-groups of children with normal language

\begin{tabular}{lcc}
\hline \multirow{2}{*}{ Sub-group } & \multicolumn{2}{c}{ Accuracy } \\
\cline { 2 - 3 } & $\%$ & SD \\
\hline Priming condition 1 $(\mathrm{N}=17)$ & 18.2 & 8.82 \\
Priming condition 2 $(\mathrm{N}=15)$ & 37.3 & 13.34 \\
Priming condition 3 $(\mathrm{N}=15)$ & 46.7 & 27.16 \\
\hline
\end{tabular}

Condition $1=$ normal priming condition group; condition $2=$ repetitive priming condition group that uses the same vocabulary; condition $3=$ repetitive priming condition group that uses different vocabulary. 
Table 3. Complex sentence production based on structural priming condition in sub-groups of children with specific language impairment

\begin{tabular}{lcc}
\hline \multirow{2}{*}{ Sub-group } & \multicolumn{2}{c}{ Accuracy } \\
\cline { 2 - 3 } & $\%$ & SD \\
\hline Priming condition 1 $(\mathrm{N}=13)$ & 14.6 & 10.50 \\
Priming condition 2 $(\mathrm{N}=12)$ & 25.0 & 19.30 \\
Priming condition 3 $(\mathrm{N}=13)$ & 18.4 & 12.81
\end{tabular}

Condition 1 =normal priming condition group; condition $2=$ repetitive priming condition group that uses the same vocabulary; condition $3=$ repetitive priming condition group that uses different vocabulary.

단순언어장애 아동 집단의 점화 방식에 따른 복문 산출 과제에서의 수행도 차이

단순언어장애 아동 집단 내 하위 집단의 점화 방식에 따른 복문 산출 과제에 대한 기술통계는 Table 3과 같다. 구문점화를 한 번 제 시한 조건에서 단순언어장애 아동은 10 점 만점에 1.46 점 $(\mathrm{SD}=1.05)$ 을 획득하여 약 $14.6 \%$ 의 정확도를 보였고, 같은 문장의 구문점화 를 두 번 제시한 조건에서 단순언어장애 아동은 10 점 만점에 2.50 점 $(\mathrm{SD}=1.93)$ 을 획득하여 약 $25 \%$ 의 정확도를 보였다. 그리고 구문 구조는 같으나 어휘가 다른 문장의 구문점화를 두 번 제시한 조건 에서는 10 점 만점에 1.84 점 $(\mathrm{SD}=1.28)$ 을 획득하여 약 $18.4 \%$ 의 정확 도를 보였다.

\section{두 집단(일반 아동, 단순언어장애 아동)의 점화 방식에 따른 복문} 산출 과제에서의 차이

집단 간(일반 아동, 단순언어장애 아동) 구문점화 방식(일반 점 화, 같은 어휘를 사용한 반복 점화, 다른 어휘를 사용한 반복 점화) 에 따른 복문 산출에 차이가 있는지 알아보기 위해 2 요인 독립측정 분산분석 $(2 \times 3$ two-way between ANOVA)을 실시한 결과, 집단에 따른 주효과가 통계적으로 유의하였다 $\left(F_{(1,79)}=16.715, p<.0001\right)$ 즉, 복문 산출에 대한 집단의 평균은 일반 아동 집단이 34.07 로 단 순언어장애 아동 집단의 평균인 19.35보다 높게 나타났다.

또한 점화 조건(일반 점화, 같은 어휘를 사용한 반복 점화, 다른 어휘를 사용한 반복 점화)에 대한 주효과도 통계적으로 유의하게 나타났는데 $\left(F_{(2,79)}=8.457, p<.0001\right)$, 조건3 (32.564), 조건2 (31.167), 조건1 (16.425) 순으로 복문 산출 점수가 크게 나타났다. 이에 따라 점화 방식에 대한 Bonferroni 사후검정을 실시한 결과, 조건1과 조건 2 , 조건 1 과조건 3 사이에 통계적으로 유의한차이가 나타났고 $(p<.05)$, 조건 2 와 조건 3 사이에는 유의한 차이가 나타나지 않았다.

또한 그룹과 점화 방식 간 이차 상호작용이 통계적으로 유의하게 나타났다 $\left(F_{(2,79)}=4.069, p<.05\right)$. 이에 따라 LMATRIX SYNTAX를 사용하여 상호작용대비검정(interaction contrast)을 실시하였다.

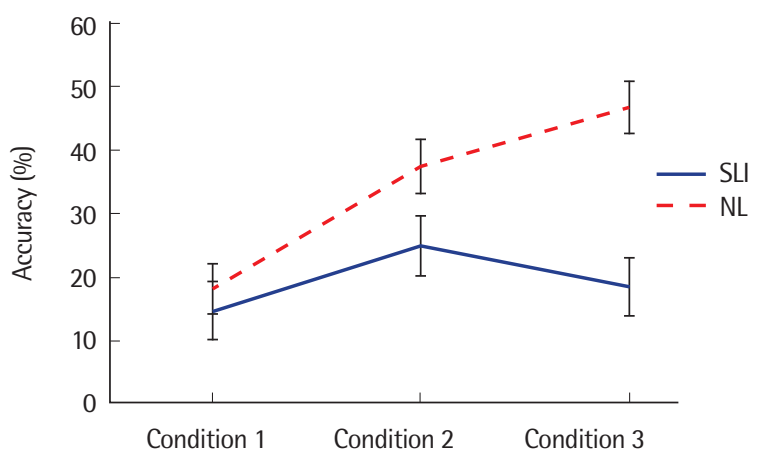

Figure 2. Complex sentence production based on structural priming method in children with specific language impairment (SLI) and children with normal language (NL). Condition $1=$ normal priming condition group; condition $2=$ repetitive priming condition group that uses the same vocabulary; condition $3=$ repetitive priming condition group that uses different vocabulary.

그 결과, 조건1과 조건2에 따른 그룹 간 차이가 통계적으로 유의하 지 않았고 $\left(F_{(1,79)}=.978, p>.05\right)$, 조건 2 와 조건 3 에 따른 그룹 차이도 통계적으로 유의하지 않았다 $\left(F_{(1,79)}=3.158, p>.05\right)$. 조건1과 조건3에 따른 그룹 간 차이만 통계적으로 유의하게 나타났다 $\left(F_{(1,79)}=7.963\right.$, $p<.05)$.

단순언어장애 아동과 일반 아동 집단의 점화 방식에 따른 복문 산출 비교 결과 그래프를 Figure 2에 제시하였다.

\section{구문점화 방식에 따른 복문 산출과 암묵적 학습 및 작업기억 간의 상관관계}

일반 아동 집단에서 구문점화에 따른 복문 산출과 암묵적 학습 및 작업기억 간의 상관관계

일반 아동 집단 내 하위 집단별로 구문점화에 따른 복문 산출과 암묵적 학습 및 작업기억 간 유의한 상관관계가 나타나는지 살펴보 기 위해 Pearson 적률상관계수를 측정하였다. 일반 아동 집단 내 일 반 점화를 실시한 점화 조건 1 의 그룹에서 구문점화에 따른 복문 산 출과 암묵적 학습 및 작업기억 간의 상관관계를 살펴본 결과, 구문 점화에 따른 복문 산출과 암묵적 학습 및 작업기억 간에 유의한 상 관이 나타나지 않았다. 그리고 같은 어휘를 사용한 반복 점화의 점 화 조건2 그룹에서 구문점화에 따른 복문 산출과 암묵적 학습 및 작업기억 간의 상관관계를 살펴본 결과, 구문점화에 따른 복문 산 출과 암묵적 학습 및 작업기억 간에 유의한 상관이 나타나지 않았 다. 마지막으로 다른 어휘를 사용한 반복 점화의 점화 조건 3 그룹에 서 구문점화에 따른 복문 산출과 암묵적 학습 및 작업기억 간의 상 관관계를 살펴본 결과, 구문점화에 따른 복문 산출과 작업기억 간 에 유의한 상관이 나타났다 $(r=.723, p<.01)$. 결과적으로, 일반 아동 집단에서는 다른 어휘를 사용한 반복 점화의 점화 조건 3 그룹에서 
만 구문점화에 따른 복문 산출과작업기억 간에 상관이 나타났다.

단순언어장애 아동 집단에서 구문점화에 따른 복문 산출과 암묵적 학습 및 작업기억 간의 상관관계

단순언어장애 아동 집단 내 하위 집단별로 구문점화에 따른 복 문 산출과 암묵적 학습 및 작업기억 간 유의한 상관관계가 나타나 는지 살펴보기 위해 Pearson 적률상관계수를 측정하였다. 단순언 어장애 아동 집단 내 일반 점화를 실시한 점화 조건1의 그룹에서 구문점화에 따른 복문 산출과 암묵적 학습 및 작업기억 간의 상관 관계를 살펴본 결과, 구문점화에 따른 복문 산출과 암묵적 학습 간 에 유의한 상관이 나타났으며 $(r=.676, p<.05)$, 구문점화에 따른 복문 산출과 작업기억 간에도 유의한 상관이 나타났다 $(r=.617$, $p<.05)$. 그리고 단순언어장애 아동 집단 내 같은 어휘를 사용한 반 복 점화의 점화 조건 2 그룹에서 구문점화에 따른 복문 산출과 암 묵적 학습 및 작업기억 간의 상관관계를 살펴본 결과, 구문점화에 따른 복문 산출과 암묵적 학습 및 작업기억 간에 유의한 상관이 나 타나지 않았다. 마지막으로 단순언어장애 아동 집단 내 다른 어휘 를 사용한 반복 점화의 점화 조건 3 그룹에서 구문점화에 따른 복 문 산출과 암묵적 학습 및 작업기억 간의 상관관계를 살펴본 결과, 구문점화에 따른 복문 산출과 암묵적 학습 및 작업기억 간에 유의 한 상관이 나타나지 않았다. 결과적으로, 단순언어장애 아동 집단 에서는 일반 점화를 실시한 점화 조건 1 의 그룹에서만 구문점화에 따른 복문 산출과 암묵적 학습 및 작업기억 간에 상관이 나타났다.

\section{논의 및 결론}

\section{단순언어장애 아동 및 일반 아동의 구문점화 방식에 따른 복문 산출 과제에서의 수행도 비교}

단순언어장애 아동과 일반 아동 간에 구문점화 방식에 따른 복 문 산출 과제 수행에 차이가 있는지 알아보기 위하여 접속문과 내 포문으로 이루어진 구문점화 과제를 실시하였다. 이때 각 집단별로 점화 방식에 따라 하위 집단을 나누었는데 구문점화 방식은 일반 점화 조건 집단(점화 조건1), 같은 어휘를 사용한 반복 점화 조건 집 단(점화 조건2), 다른 어휘를 사용한 반복 점화 조건 집단(점화 조 건3), 총 3가지의 조건으로 나누어 실시하였다.

그 결과, 점화 방식에 따라 나뉜 단순언어장애 아동과 일반 아동 내 하위 집단의 과제 수행도에 유의한 차이가 있었다. 우선 단순언 어장애 아동 집단의 경우 같은 어휘를 사용한 반복 점화 조건, 다른 어휘를 사용한 반복 점화 조건, 일반 점화 조건 순으로 수행도가 높 게 나타났으며, 일반 아동 집단의 경우는 다른 어휘를 사용한 반복
점화 조건, 같은 어휘를 사용한 반복 점화 조건, 일반 점화 조건 순 으로 수행도가 높게 나타났다.

단순언어장애 아동과 일반 아동 집단 모두 한 번의 점화를 제시 하는 일반 점화 조건보다는 두 번의 점화를 제시하는 반복 점화 조 건에서 높은 수행도를 나타냈는데, 이는 아동의 언어를 촉진할 때 어떤 방식이든 언어자극의 반복이 많을수록 긍정적인 영향을 미친 다는 것을 의미한다. 이러한 결과는 그동안 선행연구에서 이루어졌 던 어휘 학습에 있어서의 ‘반복’에 대한 연구 결과와 일치한다. 이때 ‘반복'이라는 것은 해당 언어 자극에 아동이 얼마나 노출되었는지 를 의미한다고 볼 수 있으며 대부분의 연구는 아동들의 언어 학습 이 이러한 언어 자극의 제시 빈도와 매우 밀접한 연관성을 가진다 고 밝혀왔다(Childers \& Tomasello, 2002; Gray, 2005; Gray \& Brinkley, 2011; Rice, Oetting, Marquis, Bode, \& Pae, 1994; Riches, Tomasello, \& Conti-Ramsden, 2005). 즉, 언어 자극 제시 빈도가 많을 수록 어휘 학습에 대한 아동의 수행도는 증가하는 경향을 나타내 며 이러한 사실은 언어에 어려움을 겪고 있는 아동들에 대한 중재 를 실시할 때 유용한 전략으로 사용될 수 있다. 또한 두 집단이 반 복 점화 조건에서 더 높은 수행을 나타내기는 하였으나 반복 점화 조건 중에서도 반복 제시 방식에 따른 조건에서는 다른 양상의 수 행도를 나타냈다. 단순언어장애 아동 집단의 경우에는 같은 어휘 를 사용한 문장을 두 번 제시하는 조건에서 가장 높은 수행도를 나 타냈고 일반 아동 집단의 경우에는 다른 어휘를 사용한 문장을 두 번 제시하는 조건에서 가장 높은 수행도를 나타냈다. 이는 아동들 에게 언어 자극을 제시할 때 집단에 따라 서로 다른 제시 전략을 사용해야 함을 의미한다고 볼 수 있다. 즉, 일반 아동 집단의 경우 같은 내용의 자극을 여러 번 제시하는 것보다 같은 구조 안에서 약 간의 변화를 준 자극을 여러 번 제시하는 것이 아동의 언어 산출을 이끌어 내는데 더 효과적일 수 있고, 단순언어장애 아동 집단의 경 우에는 다양한 내용의 자극을 여러 번 제시하는 것보다 같은 내용 의 자극을 여러 번 제시하는 것이 더 효과적일 수 있다. 이는 일반 아동을 대상으로 효과적인 구문점화 방식을 연구한 Savage 등 (2006)의 연구와 일치하는 결과이다. Savage 등(2006)에서는 일반 아동을 통제집단과 실험집단으로 나누어 서로 다른 점화 방식을 사용한 후 점화 효과를 연구하였는데, 다른 어휘를 사용한 점화에 서 더 큰 점화효과가 나타났다. 그리고 이 연구에서는 이러한 결과 를 ‘학습에서의 도식화’ 측면에서 설명하고 있다. 즉 무언가를 학습 하기 위해서는 일정 지식을 머리 속에 추상적으로 구조화시키는 작업이 필요한데, 이때 일반 아동에게는 다양한 어휘를 제시하는 것이 형식과 의미의 연결을 돕는다는 것이다. 같은 구조 안에서 제 시되는 다양한 의미의 변화가 구조적인 규칙성을 더 잘 파악할 수 
있게 하고, 이것은 지식의 추상적 구조화를 더 활성화 시켜 문장의 구조를 빨리 파악하게 하는 데 기여한다. 이러한 측면에서 본 연구 의 결과는 일반 아동과 단순언어장애 아동이 가지고 있는 지식의 추상적 구조화에 대한 다른 전략을 암시한다. 즉, 일반 아동은 서로 다른 많은 예시를 통해 지식의 추상적 구조화를 활성화시키지만 단순언어장애 아동은 같은 예시의 단순 반복을 통해 지식의 추상 적 구조화를 활성화시킨다. 따라서 이러한 연구결과를 참고하여 단순언어장애 아동을 대상으로 한 학습과 중재에서는 같은 내용 의 반복을 바탕으로 한 학습, 중재 방법을 모색해 보아야 할 것이다.

\section{구문점화 방식에 따른 복문 산출과 암묵적 학습 및 작업기억 간의 관계}

구문점화 방식에 따른 단순언어장애 아동과 일반 아동의 복문 산출이 암묵적 학습 및 작업기억과 연관성을 가지고 있는지 알아 보기 위하여 구문점화를 통한 복문 산출 과제와 함께 청각 통계적 학습 과제, 비단어 따라말하기 과제를 실시하였다. 그 결과, 단순언 어장애 아동 집단에서는 일반 점화를 실시한 점화 조건 1 의 집단에 서만 구문점화에 따른 복문 산출과 암묵적 학습 및 작업기억 간에 상관이 나타났다. 그리고 같은 어휘를 반복한 점화 조건2의 집단과 다른 어휘를 반복한 점화 조건 3 의 집단에서는 암묵적 학습 및 작업 기억과 점화를 통한 복문 산출 간에 어떠한 상관관계도 나타나지 않았다. 일반 아동 집단에서는 다른 어휘를 반복한 점화 조건3의 집단에서만 구문점화에 따른 복문 산출과 작업기억 간에 상관이 나타났으며, 일반 점화를 실시한 점화 조건 1 의 집단과 같은 어휘를 반복한 점화 조건 2 의 집단에서는 암묵적 학습 및 작업기억과 점화 를 통한 복문 산출 간에 어떠한 상관관계도 나타나지 않았다. 이러 한 결과는 총 3 가지 측면에서 설명될 수 있다.

첫째, 두 집단의 비단어 따라말하기 수행과 통계적 학습 수행에 대한 표준편차를 통해 이러한 상관관계를 설명할 수 있다. 단순언 어장애 아동의 경우 점화 조건 2 집단과 점화 조건 3 집단 아동들이 보여준 과제 수행도의 표준편차가 점화 조건1 집단 아동들의 과제 수행도 표준편차에 비해 낮게 나타났다. 그리고 일반 아동의 경우 비단어 따라말하기 과제 수행도에 대한 표준편차가 점화 조건1, 점 화 조건2에서 낮게 나타나 복문 산출과의 상관을 나타내지 못하였 다. 즉, 낮게 나타난 과제 수행도의 표준편차 때문에 집단별, 조건별 로 다른 상관관계가 나타난 것이라고 볼 수 있다.

둘째, 일반 점화를 실시하는 점화 조건1에서 일반 아동의 복문 산출 결과는 암묵적 학습, 작업기억 모두와 아무런 상관관계를 보 이지 않았으나 단순언어장애 아동의 복문 산출 결과는 암묵적 학 습, 작업기억 모두와 유의한 상관관계를 나타냈다. 이러한 결과는
아무런 전략이 적용되지 않은 언어 자극 제시 상황에서 단순언어 장애 아동의 경우 다양한 언어 기저 요인들이 언어 산출과 영향을 주고 받아야 하지만 일반 아동의 경우 특별한 기저 요인의 작용 없 이도 언어 산출이 가능하다는 것을 암시한다고 볼 수 있다. 이것은 일반 아동이 단순언어장애 아동과 비교했을 때 높은 수준의 암묵 적 학습 능력과 작업기억 능력을 가지고 있기 때문일 수도 있고, 본 연구에 참여했던 아동들의 평균 연령을 생각했을 때, 일반 아동들 의 경우 일정 연령에 이르면 더 이상 암묵적 학습 능력과 작업기억 능력이 발달하지 않는다는 선행연구의 결과에 의한 것일 수도 있겠 다(Saffran et al., 1997). 따라서 본 결과에 따라 단순언어장애 아동 을 대상으로 중재를 실시할 때, 언어 외에도 작업기억, 암묵적 학습 능력과 같은 언어의 기저가 되는 요인들의 능력도 고려해 보아야 할 것이다.

또한 다른 어휘를 사용하는 반복 점화인 점화 조건3에서 일반 아동의 복문 산출 결과는 작업기억 능력과 상관관계를 나타냈으나 단순언어장애 아동의 복문 산출 결과는 어떠한 능력과도 상관관 계를 나타내지 않았다. 이러한 결과는 일반 점화 조건이나, 같은 어 휘를 반복하는 점화 조건과는 달리 다양한 예를 통해 형식과 의미 를 계속해서 연결시켜야 하는 점화 조건 3 의 언어 제시 전략과 관련 이 있다고 볼 수 있다. 앞에서 언급한 것과 같이 단순언어장애 아동 의 경우 같은 예시의 단순 반복이 지식의 추상적 구조화를 활성화 시키는 데 더 효과적이었기 때문에 서로 다른 예시를 통해 지식의 추상적 구조화를 활성화시키는 전략을 사용했던 점화 조건3에서 높은 수행률을 보이지 못하였고, 이러한 결과는 암묵적 학습 능력, 작업기억 능력과의 어떠한 상관도 이끌어내지 못하였다. 그러나 일 반 아동의 경우 서로 다른 예시가 지식의 추상적 구조화를 활성화 시키는 데 효과적이었기 때문에 이러한 전략을 사용했던 점화 조건 3에서 높은 수행률을 보여주었고, 이러한 결과는 작업기억 능력과 의 유의한 상관관계를 이끌었다. 이때, 암묵적 학습과 복문 산출이 상관을 나타내지 않은 것은 일반 아동들의 경우 구문점화 과제에 서 사용되었던 문장 구조에 대한 이해와 산출 능력이 뛰어나기 때 문에, 암묵적 학습 능력보다는 문장을 기억하는 능력이 과제를 수 행하는 데 더 중요하게 작용했을 것이라 생각된다. 즉, 암묵적 학습 능력보다는 작업기억 능력에 대한 차이가 점화 조건 3 에서의 복문 산출에 대한차이를 이끌었을 것이다.

결론적으로 단순언어장애 아동과 일반 아동 간에 구문점화 방 식에 따른 복문 산출 과제 수행에 차이가 있는지 알아보기 위하여 구문점화 과제를 실시한 결과 단순언어장애 아동과 일반 아동 집 단 모두 한 번의 점화를 제시하는 일반 점화 조건보다는 두 번의 점 화를 제시하는 반복 점화 조건에서 높은 수행도를 나타냈다. 하지 
만 단순언어장애 아동 집단의 경우에는 같은 어휘를 사용한 문장 을 두 번 제시하는 조건에서 가장 높은 수행도를 나타냈고 일반 아 동 집단의 경우에는 다른 어휘를 사용한 문장을 두 번 제시하는 조 건에서 가장 높은 수행도를 나타냈다. 이러한 결과는 아동의 언어 를 촉진할 때 언어자극 제시의 반복이 많을수록 긍정적인 영향을 미친다는 것을 의미하며, 반복 조건에 따라 두 집단의 수행도에 차 이가 나타나는 것은 각 집단이 가지고 있는 추상적 구조화에 대한 다른 전략을 암시한다. 따라서 이러한 연구결과를 참고하여 단순언 어장애 아동을 대상으로 한 학습과 중재에서는 같은 내용의 반복 을 바탕으로 한 학습, 중재 방법을 적용하는 것이 효과적일 것이라 고 생각된다. 또한 단순언어장애 아동과 일반 아동의 복문 산출이 암묵적 학습 및 작업기억과 연관성을 가지고 있는지 알아보기 위하 여 구문점화를 통한 복문 산출 과제와 함께 청각 통계적 학습 과제, 비단어 따라말하기 과제를 실시한 결과 집단과 점화 조건에 따라 각 기저 요인들과의 상관관계가 다르게 나타났다. 특히 주목할만한 결과는 아무런 전략이 적용되지 않은 언어 자극 제시 상황에서 일 반 아동의 경우 특별한 기저 요인의 작용 없이도 언어 산출이 가능 하지만 단순언어장애 아동의 경우에는 다양한 언어 기저 요인들이 언어 산출과 영향을 주고 받아야 한다는 것이다. 따라서 단순언어 장애 아동을 대상으로 중재를 실시할 때에는 언어 외에 작업기억, 암묵적 학습 능력과 같은 언어의 기저가 되는 요인들의 능력도 고려 해 보고, 이에 맞는 과제나 활동들로 회기를 구성해야할 것이다.

\section{REFERENCES}

Adams, A. M., \& Gathercole, S. E. (1995). Phonological working memory and speech production in preschool children. Journal of Speech, Language, and Hearing Research, 38, 403-414.

Baddeley, A. (1992). Working memory. Science, 255, 556-559.

Bloom, L., Lahey, M., Hood, L., Lifter, K., \& Fiess, K. (1980). Complex sentences: acquisition of syntactic connectives and the semantic relations they encode. Journal of Child Language, 7, 235-261.

Bock, J. K. (1986). Syntactic persistence in language production. Cognitive Psychology, 18, 355-387.

Bock, K., \& Griffin, Z. M. (2000). The persistence of structural priming: transient activation or implicit learning? Journal of Experimental Psychology: General, 129, 177-192.

Bock, K., \& Loebell, H. (1990). Framing sentences. Cognition, 35, 1-39.

Bowerman, M. (1979). The acquisition of complex sentences. In D. Nehls (Ed.), Studies in language acquisition (pp. 285-305). Heidelberg: Groos.
Chang, F., Dell, G. S., \& Bock, K. (2006). Becoming syntactic. Psychological Review, 113, 234-272.

Chang, F., Dell, G. S., Bock, K., \& Griffin, Z. M. (2000). Structural priming as implicit learning: a comparison of models of sentence production. Journal of Psycholinguistic Research, 29, 217-230.

Childers, J. B., \& Tomasello, M. (2002). Two-year-olds learn novel nouns, verbs, and conventional actions from massed or distributed exposures. Developmental Psychology, 38, 967-978.

Cleland, A. A., \& Pickering, M. J. (2003). The use of lexical and syntactic information in language production: evidence from the priming of nounphrase structure. Journal of Memory and Language, 49, 214-230.

Evans, J. L., Saffran, J. R., \& Robe-Torres, K. (2009). Statistical learning in children with specific language impairment. Journal of Speech, Language, and Hearing Research, 52, 321-335.

Ferreira, V. S., \& Bock, K. (2006). The functions of structural priming. Language and Cognitive Processes, 21, 1011-1029.

Foltz, A., Thiele, K., Kahsnitz, D., \& Stenneken, P. (2015). Children's syntactic-priming magnitude: lexical factors and participant characteristics. Journal of Child Language, 42, 932-945.

Gámez, P. B., \& Shimpi, P. M. (2016). Structural priming in Spanish as evidence of implicit learning. Journal of Child Language, 43, 207-233.

Gathercole, S. E., \& Baddeley, A. D. (1990). Phonological memory deficits in language disordered children: is there a causal connection? Journal of Memory and Language, 29, 336-360.

Gleason, J. B. (2005). The development of language (6th ed.). Boston, MA: Allyn \& Bacon.

Graf Estes, K., Evans, J. L., Alibali, M. W., \& Saffran, J. R. (2007). Can infants map meaning to newly segmented words? Statistical segmentation and word learning. Psychological Science, 18, 254-260.

Gray, S. (2005). Word learning by preschoolers with specific language impairment: effect of phonological or semantic cues. Journal of Speech, Language, and Hearing Research, 48, 1452-1467.

Gray, S., \& Brinkley, S. (2011). Fast mapping and word learning by preschoolers with specific language impairment in a supported learning context: effect of encoding cues, phonotactic probability, and object familiarity. Journal of Speech, Language, and Hearing Research, 54, 870-884.

Griffin, Z. M., \& Weinstein-Tull, J. (2003). Conceptual structure modulates structural priming in the production of complex sentences. Journal of Memory and Language, 49, 537-555.

Huttenlocher, J., Vasilyeva, M., \& Shimpi, P. (2004). Syntactic priming in young 
children. Journal of Memory and Language, 50, 182-195.

Hwang, M. (2003). Sentence comprehension of Korean children with specific language impairments. Korean Journal of Communication Disorders, 8, 1-21.

Johnston, J. R., \& Kamhi, A. G. (1984). Syntactic and semantic aspects of the utterances of language-impaired children: the same can be less. MerrillPalmer Quarterly, 30, 65-85.

Just, M. A., \& Carpenter, P. A. (1992). A capacity theory of comprehension: individual differences in working memory. Psychological Review, 99, 122149.

Kim, S. Y., \& Pae, S. (2002). The use of grammatical morphemes of Korean children with language impairment. Speech Science, 9, 77-91.

Kim, Y. T. (2014). Assessment and Treatment of Language Disorders in Children (2nd ed.). Seoul: Hakjisa.

Kim, Y. T., Hong, G. H., Kim, K. H., Jang, H. S., \& Lee, J. Y. (2009). Receptive \& expressive vocabulary test (REVT). Seoul: Seoul Community Rehabilitation Center.

Kweon, Y. H., \& Kim, Y. W. (2004). Relation of verbal working memory to sentence comprehension in children with specific language impairment. Korean Journal of Communication Disorders, 9, 33-48.

Kwon, D. H., \& Jung, B. S. (1999). A study of development of complex sentences in the normal children aged form 2 to 5 years. Journal of Speech \& Hearing Disorders, 8, 157-173.

Lany, J., \& Saffran, J. R. (2010). From statistics to meaning infants' acquisition of lexical categories. Psychological Science, 21, 284-291.

Lee, C. M., Jeong, M. R., \& Hwang, M. N. (2013). Word ordering skills of typically developing children and SLI in elementary school. Journal of Speech \& Hearing Disorders, 22, 147-167.

Lee, I. S., \& Chae, W. (2011). The Korean grammar. Seoul: Hakyeunsa.

Lee, J., Choi, S., \& Hwang, M. (2014). Production of case-markers during sentence repetition in Korean children with specific language impairment. Communication Sciences \& Disorders, 19, 477-485.

Lee, Y. (2007). Validity and reliability analyses of the language test for schoolage children. Korean Journal of Communication Disorders, 12, 569-586.

Lee, Y. (2010). The development of complex sentence production of schoolaged children. Journal of Speech \& Hearing Disorders, 19, 159-178.

Leonard, L. B. (1998). Children with specific language impairment. Cambridge, MA: MIT Press.

Leonard, L. B. (2011). The primacy of priming in grammatical learning and intervention: a tutorial. Journal of Speech, Language, and Hearing Research, $54,608-621$.
Limber, J. (1973). The genesis of complex sentences. In T. E. Moore (Ed.), Cognitive development and the acquisition of language (pp. 169-186). New York, NY: Academic Press.

Montgomery, J. W. (1995). Sentence comprehension in children with specific language impairment: the role of phonological working memory. Journal of Speech, Language, and Hearing Research, 38, 187-199.

Moon, S. B., \& Byun, C. J. (2003). Korean Kaufman assessment battery for children (K-ABC). Seoul: Hakjisa.

Morehead, D. M., \& Ingram, D. (1973). The development of base syntax in normal and linguistically deviant children. Journal of Speech, Language, and Hearing Research, 16, 330-352.

Nippold, M. A., Mansfield, T. C., \& Billow, J. L. (2007). Peer conflict explanations in children, adolescents, and adults: examining the development of complex syntax. American Journal of Speech-Language Pathology, 16, 179188.

Oh, D. Y., \& Yim, D. (2013). Non-word repetition and sentence repetition performance in 2-3 years old late talkers and normal children. Communication Sciences \& Disorders, 18, 277-287.

Pae, S., Lim, S. S., Lee, J. H., \& Jang, H. S. (2004). Korean Oral Syntax Expression Comprehension Test (KOSECT). Seoul: Seoul Community Rehabilitation Center.

Pickering, M. J., \& Branigan, H. P. (1998). The representation of verbs: evidence from syntactic priming in language production. Journal of Memory and Language, 39, 633-651.

Pickering, M. J., \& Ferreira, V. S. (2008). Structural priming: a critical review. Psychological Bulletin, 134, 427-459.

Reber, A. S. (1967). Implicit learning of artificial grammars. Journal of Verbal Learning and Verbal Behavior, 6, 855-863.

Rice, M. L., Oetting, J. B., Marquis, J., Bode, J., \& Pae, S. (1994). Frequency of input effects on word comprehension of children with specific language impairment. Journal of Speech, Language, and Hearing Research, 37, 106122.

Riches, N. G., Tomasello, M., \& Conti-Ramsden, G. (2005). Verb learning in children with SLI: frequency and spacing effects. Journal of Speech, Language, and Hearing Research, 48, 1397-1411.

Saffran, J. R., Aslin, R. N., \& Newport, E. L. (1996). Statistical learning by 8-month-old infants. Science, 274, 1926-1928.

Saffran, J. R., Newport, E. L., Aslin, R. N., Tunick, R. A., \& Barrueco, S. (1997). Incidental language learning: listening (and learning) out of the corner of your ear. Psychological Science, 8, 101-105. 
Savage, C., Lieven, E., Theakston, A., \& Tomasello, M. (2006). Structural priming as implicit learning in language acquisition: the persistence of lexical and structural priming in 4-year-olds. Language Learning and Development, 2, 27-49.

Seo, H. S., \& Lee, S. H. (1999). The development of connective endings of 2-5 year old normal children. Korean Journal of Communication Disorders, 9, 167-185.

Tomblin, J. B., Mainela-Arnold, E., \& Zhang, X. (2007). Procedural learning in adolescents with and without specific language impairment. Language Learning and Development, 3, 269-293.

Ullman, M. T. (2004). Contributions of memory circuits to language: the declarative/procedural model. Cognition, 92, 231-270.

Vinter, A., \& Perruchet, P. (2000). Implicit learning in children is not related to age: evidence from drawing behavior. Child Development, 71, 1223-1240.
Weismer, S. E. (1996). Capacity limitations in working memory: the impact on lexical and morphological learning by children with language impairment. Topics in Language Disorders, 17, 33-44.

Yang, Y., Yim, D., Kim, S., \& Han, J. (2013). The relationship among receptive vocabulary, non-word repetition, and quick incidental learning in preschoolers with and without delay in vocabulary development. Communication Sciences \& Disorders, 18, 379-391.

Yim, D., Yang, Y., \& Kim, S. (2015). Domain-specific working memory performance in children with and without specific language impairment. Communication Sciences \& Disorders, 20, 13-23.

Yim, D., Kwak, A., Lee, Y., Han, W., Lee, J., Chun, S., ... \& Han, J. (2016). Statistical learning in children with primary language impaitment (PLI). Journal of Speech-Language \& Hearing Disorders, 25, 61-69. 
Appendix 1. 점화 조건1, 점화 조건2의 복문 산출 과제

〈연습문항〉

\begin{tabular}{llll}
\hline 번호 & 문장구조 & \multicolumn{1}{c}{ 제시 문장 } & 목표 반응 \\
\hline 점화문장 & 접속-대등 & 호랑이는 춤춘다. & 호랑이는 춤추고 여우는 노래한다. \\
목표문장 & 접속-대등 & 날씨가 춥다. & 비가 온다.
\end{tabular}

〈접속〉

\begin{tabular}{|c|c|c|c|}
\hline 번호 & 문장구조 & 제시 문장 & 목표 반응 \\
\hline 점화문장1 & 접속-대립 & $\begin{array}{l}\text { 눈이 왔다. } \\
\text { 날씨는 따뜻하다. }\end{array}$ & 눈이 왔지만 날씨는 따뜻하다. \\
\hline 목표문장1 & 접속-대립 & $\begin{array}{l}\text { 집은 조용하다. } \\
\text { 밖은 시끄럽다. }\end{array}$ & 집은 조용하지만 밖은 시끄럽다. \\
\hline 점화문장2 & 접속-대등 & $\begin{array}{l}\text { 상아 가방은 무겁다. } \\
\text { 상진이 가방은 가볍다. }\end{array}$ & 상아 가방은 무겁고 상진이 가방은 가볍다. \\
\hline 목표문장2 & 접속-대등 & $\begin{array}{l}\text { 우리 강아지는 크다. } \\
\text { 친구 강아지는 작다. }\end{array}$ & 우리 강아지는 크고 친구 강아지는 작다. \\
\hline 점화문장3 & 접속-인과 & $\begin{array}{l}\text { 바람이 불었다. } \\
\text { 나뭇잎이 떨어졌다. }\end{array}$ & 바람이 불어서 나뭇잎이 떨어졌다. \\
\hline 목표문장3 & 접속-인과 & $\begin{array}{l}\text { 텔레비전 소리가 시끄럽다. } \\
\text { 귀가 아프다. }\end{array}$ & 텔레비전 소리가 시끄러워서 귀가 아프다. \\
\hline 점화문장4 & 접속-조건 & $\begin{array}{l}\text { 선생님이 되고 싶다. } \\
\text { 공부를 열심히 해야 한다. }\end{array}$ & 선생님이 되고 싶으면 공부를 열심히 해야 한다 \\
\hline 목표문장4 & 접속-조건 & $\begin{array}{l}\text { 키가 크고 싶다. } \\
\text { 운동을 열심히 해야 한다. }\end{array}$ & 키가 크고 싶으면 운동을 열심히 해야 한다. \\
\hline 점화문장5 & 접속-의도 & $\begin{array}{l}\text { 나는 밥을 먹으려고 한다. } \\
\text { 식탁에 앉았다. }\end{array}$ & 나는 밥을 먹으려고 식탁에 앉았다. \\
\hline 목표문장5 & 접속-의도 & $\begin{array}{l}\text { 나는 옷을 입으려고 한다. } \\
\text { 방에 들어왔다. }\end{array}$ & 나는 옷을 입으려고 방에 들어왔다. \\
\hline
\end{tabular}

〈내포〉

\begin{tabular}{|c|c|c|c|}
\hline 번호 & 문장구조 & 제시 문장 & 목표 반응 \\
\hline 점화문장6 & 내포-관형 & $\begin{array}{l}\text { 피자는 맛있다. } \\
\text { 피자는 음식이다. }\end{array}$ & 피자는 맛있는 음식이다. \\
\hline 목표문장6 & 내포-관형 & $\begin{array}{l}\text { 고양이는 귀엽다 } \\
\text { 고양이는 동물이다. }\end{array}$ & 고양이는 귀여운 동물이다. \\
\hline 점화문장7 & 내포-관형 & $\begin{array}{l}\text { 이 바지는 길다. } \\
\text { 형은 그 바지를 벗었다. }\end{array}$ & 형은 긴 바지를 벗었다. \\
\hline 목표문장7 & 내포-관형 & $\begin{array}{l}\text { 이 장미가 빨갛다. } \\
\text { 나는 그 장미를 꺾었다. }\end{array}$ & 나는 빨간 장미를 꺾었다. \\
\hline 점화문장8 & 내포-관형 & $\begin{array}{l}\text { 이 아이스크림이 맛있다. } \\
\text { 그 아이스크림은 동생의 것이다. }\end{array}$ & 이 맛있는 아이스크림은 동생의 것이다. \\
\hline 목표문장8 & 내포-관형 & $\begin{array}{l}\text { 이 장갑은 비싸다. } \\
\text { 그 장갑은 누나의 것이다. }\end{array}$ & 이 비싼 장갑은 누나의 것이다. \\
\hline 점화문장9 & 내포-관형 & $\begin{array}{l}\text { 이 딸기가 크다. } \\
\text { 나는 그 딸기를 먹었다. }\end{array}$ & 나는 큰 딸기를 먹었다. \\
\hline 목표문장9 & 내포-관형 & $\begin{array}{l}\text { 이 책은 재밌다. } \\
\text { 나는 츠 책을 읽었다. }\end{array}$ & 나는 재밌는 책을 읽었다. \\
\hline 점화문장10 & 내포-관형 & $\begin{array}{l}\text { 나는 연필을 주웠다. } \\
\text { 그 연필이 뾰족하다. }\end{array}$ & 나는 뾰족한 연필을 주웠다. \\
\hline 목표문장10 & 내포-관형 & $\begin{array}{l}\text { 나는 신발을 잃어버렸다. } \\
\text { 그 신발은 귀엽다. }\end{array}$ & 나는 귀여운 신발을 잃어버렸다. \\
\hline
\end{tabular}


Appendix 2. 점화 조건3의 복문 산출 과제

〈연습문항〉

\begin{tabular}{llll}
\hline 번호 & 문장구조 & \multicolumn{1}{c}{ 제시 문장 } & 목표 반응 \\
\hline 점화문장1 & 접속-대등 & 호랑이는 춤춘다. & 호랑이는 춤추고 여우는 노래한다. \\
점화문장2 & 접속-대등 & 연필은 뽀족하다. & 연필은 뾰족하고 공은 둥글다. \\
& 겅슨 둥들다. & 날씨가 춥고 비가 온다. \\
& 접작대등 & 날씨가 춥다. & \\
& 비가 온다. & \\
\hline
\end{tabular}

〈접속〉

\begin{tabular}{|c|c|c|c|}
\hline 번호 & 문장구조 & 제시 문장 & 목표 반응 \\
\hline 점화문장1-1 & 접속-대립 & $\begin{array}{l}\text { 눈이 왔다. } \\
\text { 날씨는 따뜻하다. }\end{array}$ & 눈이 왔지만 날씨는 따뜻하다. \\
\hline 점화문장1-2 & 접속-대립 & $\begin{array}{l}\text { 옷은 작다. } \\
\text { 모자는 크다. }\end{array}$ & 옷은 작지만 모자는 크다. \\
\hline 목표문장1 & 접속-대립 & $\begin{array}{l}\text { 집은 조용하다. } \\
\text { 밖은 시끄럽다. }\end{array}$ & 집은 조용하지만 밖은 시끄럽다. \\
\hline 점화문장2-1 & 접속-대등 & $\begin{array}{l}\text { 상아 가방은 무겁다. } \\
\text { 상진이 가방은 가볍다. }\end{array}$ & 상아 가방은 무겁고 상진이 가방은 가볍다. \\
\hline 점화문장2-2 & 접속-대등 & $\begin{array}{l}\text { 내 신발은 빨갛다. } \\
\text { 동생 신발은 파랗다. }\end{array}$ & 내 신발은 빨갛고 동생 신발은 파랗다. \\
\hline 목표문장2 & 접속-대등 & $\begin{array}{l}\text { 우리 강아지는 크다. } \\
\text { 친구 강아지는 작다. }\end{array}$ & 우리 강아지는 크고 친구 강아지는 작다. \\
\hline 점화문장3-1 & 접속-인과 & $\begin{array}{l}\text { 바람이 불었다. } \\
\text { 나뭇잎이 떨어졌다. }\end{array}$ & 바람이 불어서 나뭇잎이 떨어졌다. \\
\hline 점화문장3-2 & 접속-인과 & $\begin{array}{l}\text { 아기가 넘어졌다. } \\
\text { 엄마가 놀랐다. }\end{array}$ & 아기가 넘어져서 엄마가 놀랐다. \\
\hline 목표문장3 & 접속-인과 & $\begin{array}{l}\text { 텔레비전 소리가 시끄럽다. } \\
\text { 귀가 아프다. }\end{array}$ & 텔레비전 소리가 시끄러워서 귀가 아프다. \\
\hline 점화문장4-1 & 접속-조건 & $\begin{array}{l}\text { 선생님이 되고 싶다. } \\
\text { 공부를 열심히 해야 한다. }\end{array}$ & 선생님이 되고 싶으면 공부를 열심히 해야 한다. \\
\hline 점화문장4-2 & 접속-조건 & $\begin{array}{l}\text { 글씨를 쓰려고 한다. } \\
\text { 연습을 열심히 해야 한다. }\end{array}$ & 글씨를 쓰려면 연습을 열심히 해야 한다. \\
\hline 목표문장4 & 접속-조건 & $\begin{array}{l}\text { 키가 크고 싶다. } \\
\text { 운동을 열심히 해야 한다. }\end{array}$ & 키가 크고 싶으면 운동을 열심히 해야 한다. \\
\hline 점화문장5-1 & 접속-의도 & $\begin{array}{l}\text { 나는 밥을 먹으려고 한다. } \\
\text { 식탁에 앉았다. }\end{array}$ & 나는 밥을 먹으려고 식탁에 앉았다. \\
\hline 점화문장5-2 & 접속-의도 & $\begin{array}{l}\text { 나는 잠을 자려고 한다. } \\
\text { 침대에 누웠다. }\end{array}$ & 나는 잠을 자려고 침대에 누웠다. \\
\hline 목표문장5 & 접속-의도 & $\begin{array}{l}\text { 나는 옷을 입으려고 한다. } \\
\text { 방에 들어왔다. }\end{array}$ & 나는 옷을 입으려고 방에 들어왔다. \\
\hline
\end{tabular}


Appendix 2. Continued

〈내포〉

\begin{tabular}{|c|c|c|c|}
\hline 번호 & 문장구조 & 제시 문장 & 목표 반응 \\
\hline 점화문장6-1 & 내포-관형 & $\begin{array}{l}\text { 피자는 맛있다. } \\
\text { 피자는 음식이다. }\end{array}$ & 피자는 맛있는 음식이다. \\
\hline 점화문장6-2 & 내포-관형 & $\begin{array}{l}\text { 바나나는 노랗다. } \\
\text { 바나나는 과일이다. }\end{array}$ & 바나나는 노란 과일이다. \\
\hline 목표문장6 & 내포-관형 & $\begin{array}{l}\text { 고양이는 귀엽다 } \\
\text { 고양이는 동물이다. }\end{array}$ & 고양이는 귀여운 동물이다. \\
\hline 점화문장7-1 & 내포-관형 & $\begin{array}{l}\text { 이 바지는 길다. } \\
\text { 형은 그 바지를 벗었다. }\end{array}$ & 형은 긴 바지를 벗었다. \\
\hline 점화문장7-2 & 내포-관형 & $\begin{array}{l}\text { 이 가방은 크다. } \\
\text { 엄마는 그 가방을 버렸다. }\end{array}$ & 엄마는 큰 가방을 버렸다. \\
\hline 목표문장7 & 내포-관형 & $\begin{array}{l}\text { 이 장미가 빨갛다. } \\
\text { 나는 그 장미를 꺾었다. }\end{array}$ & 나는 빨간 장미를 꺾었다. \\
\hline 점화문장8-1 & 내포-관형 & $\begin{array}{l}\text { 이 아이스크림이 맛있다. } \\
\text { 그 아이스크림은 동생의 것이다. }\end{array}$ & 이 맛있는 아이스크림은 동생의 것이다 \\
\hline 점화문장8-2 & 내포-관형 & $\begin{array}{l}\text { 이 옷은 파랗다. } \\
\text { 그 옷은 아빠의 것이다. }\end{array}$ & 이 파란 옷은 아빠 것이다. \\
\hline 목표문장8 & 내포-관형 & $\begin{array}{l}\text { 이 장갑은 비싸다. } \\
\text { 그 장갑은 누나의 것이다. }\end{array}$ & 이 비싼 장갑은 누나의 것이다. \\
\hline 점화문장9-1 & 내포-관형 & $\begin{array}{l}\text { 이 딸기가 크다. } \\
\text { 나는 그 딸기를 먹었다. }\end{array}$ & 나는 큰 딸기를 먹었다. \\
\hline 점화문장9-2 & 내포-관형 & $\begin{array}{l}\text { 이 운동화가 멋지다. } \\
\text { 나는 그 운동화를 샀다. }\end{array}$ & 나는 멋진 운동화를 샀다. \\
\hline 목표문장9 & 내포-관형 & $\begin{array}{l}\text { 이 책은 재밌다. } \\
\text { 나는 그 책을 읽었다. }\end{array}$ & 나는 재밌는 책을 읽었다. \\
\hline 점화문장 10-1 & 내포-관형 & $\begin{array}{l}\text { 나는 연필을 주웠다. } \\
\text { 그 연필이 뾰족하다. }\end{array}$ & 나는 뾰족한 연필을 주웠다. \\
\hline 점화문장 10-2 & 내포-관형 & $\begin{array}{l}\text { 엄마가 인형을 사줬다. } \\
\text { 그 인형은 작다. }\end{array}$ & 엄마가 작은 인형을 사줬다. \\
\hline 목표문장10 & 내포-관형 & $\begin{array}{l}\text { 나는 신발을 잃어버렸다. } \\
\text { 그 신발은 귀엽다. }\end{array}$ & 나는 귀여운 신발을 잃어버렸다. \\
\hline
\end{tabular}




\title{
국문초록
}

\author{
단순언어장애 아동의 구문점화 방식에 따른 복문 산출 능력과 암묵적 학습 및 작업기억 간의 관계 \\ 한우주 · 임동선 \\ 이화여자대학교 일반대학원 언어병리학과
}

배경 및 목적: 본 연구에서는 구문점화 조건을 달리한 복문산출 과제를 실시한 후 이에 대한 수행이 단순언어장애 아동과 일반 아동 간에 다르게 나타나는지를 알아보고, 그룹에 따라 달라지는 언어 자극 제시 전략을 모색해보고자 한다. 또한 점화 방식에 따른 복문 산 출이 언어 발달의 기저요인이라고 알려진 작업기억, 암묵적 학습과 어떠한 관련이 있는지를 알아보고, 이것이 단순언어장애 아동 집단 의 중재에서 어떠한 의미를 함축할 수 있는지 알아보고자 하였다. 방법: 5-7세의 단순언어장애 아동 38명, 생활연령을 일치시킨 일반 아 동 47명을 대상으로 조건을 달리한 복문 산출과제, 비단어 따라말하기 과제, 청각 통계적 학습 과제를 실시하였다. 결과: 연구 결과 단 순언어장애 아동과 일반 아동 집단 모두 두 번의 점화를 제시하는 반복 점화 조건에서 높은 수행도를 나타냈으며, 반복 제시 방식에 따 른 조건에서는 두 집단 간 다른 양상의 수행도가 나타났다. 구문점화 방식에 따른 복문 산출과 암묵적 학습, 작업기억 간의 상관관계에 서도 두 집단은 다른 양상을 나타냈다. 논의 및 결론: 본 연구의 결과는 단순언어장애 아동들에게 언어 자극을 제시할 때는 차별화된 제시 전략을 사용해야 하며 집단과 방식에 따라 언어 산출에 작용되는 기저 요인이 다르다는 것을 암시한다.

핵심어: 구문점화, 복문산출, 작업기억, 암묵적 학습, 단순언어장애

이 논문은 제 1 저자의 석사학위논문의 일부를 발췌한 것임.

\section{참고문헌}

권도하, 정분선(1999). 2-5 세 유아의 복문 발달에 관한 연구. 언어치료연구, 8, 157-173.

권유현, 김영욱(2004). 단순언어장애 아동의 언어성 작업기억과 문장이해간의 관계. 언어청각장애연구, 9, 33-48.

김수영, 배소영(2002). 언어발달지체아동의 문법형태소 사용 특성. 음성과학, 9, 77-91.

김영태(2014). 아동언어장애의 진단 및 치료(제2판). 서울: 학지사.

김영태, 홍경훈, 김경희, 장혜성, 이주연(2009). 수용·표현어휘력검사(REVT). 서울: 서울장애인종합복지관.

문수백, 변창진(2003). K-ABC 교육·심리측정도구(Korean-Kaufman assessment battery for children). 서울: 학지사.

배소영, 임선숙, 이지희, 장혜성(2004). 구문의미이해력 검사. 서울: 서울장애인종합복지관.

서희선, 이승환(1999). 2-5 세 정상 아동의 연결어미 발달. 언어청각장애연구, 9, 167-185.

양윤희, 임동선, 김신영, 한지윤(2013). 학령 전 어휘발달지체 및 일반 아동의 비단어 따라 말하기, 빠른 우연학습과 수용어휘와의 관계. 언어청각장애

연구, 18, 379-391.

오다연, 임동선(2013). 2-3세 말 늦은 아동과 정상 아동의 비단어 따라말하기와 문장 따라말하기 수행 능력. 언어청각장애연구, 18, 277-287.

이윤경(2007). 학령기 언어검사도구 개발: 타당도와 신뢰도 분석을 중심으로. 언어청각장애연구, 12, 569-586.

이윤경(2010). 문장 연결과제를 통한 초등학생의 복문 산출 발달. 언어치료연구, 19, 159-178.

이익섭, 채완(2011). 국어문법론강의. 서울: 학연사.

이정미, 최소영, 황민아(2014). 문장 따라말하기에서 나타난 단순언어장애아동의 조사처리능력. 언어청각장애연구, 19, 477-485.

이찬미, 정미란, 황민아(2013). 학령기 단순언어장애아동과 일반아동의 문장구성하기. 언어치료연구, 22, 147-167.

임동선, 양윤희, 김신영(2015). 단순언어장애 아동과 일반 아동의 작업기억 제시방식 및 과제유형에 따른 수행능력 비교. 언어청각장애연구, 20, 13-23. 임동선, 곽아람, 이여진, 한우주, 이지혜, 천소연, 이슬기, 한지윤(2016). 일차성 언어장애(PLI) 아동의 통계적 학습능력. 언어치료연구, 25, 61-69. 황민아(2003). 단순언어장애아동의 문장 이해: 단서이용 양상을 중심으로. 언어청각장애연구, 8, 1-21. 